\title{
HYDROGEL NANOPARTICLE ENCAPSULATED PLASMID AS A SUITABLE GENE DELIVERY SYSTEM
}

\author{
A. RAFIEE ${ }^{1}$, F. RIAZI-RAD ${ }^{2}$, M.H. ALIMOHAMMADIAN ${ }^{2}$, T. GAZORI ${ }^{3}$ \\ S.M.R. FATEMI ${ }^{4}$, M. HAVASKARY ${ }^{5}$ \\ ${ }^{1}$ Department of Biology, Central Tehran Branch, Islamic Azad University, Tehran, Iran \\ ${ }^{2}$ Immunology Department, Pasteur institute of Iran, Tehran, Iran \\ ${ }^{3}$ Department of Pharmaceutics, Faculty of Pharmacy, Tehran University of Medical Sciences (TUMS), Tehran, Iran \\ ${ }^{4}$ Islamic Azad University, Science and Research Branch, Department of Marine Biology, Tehran, Iran \\ ${ }^{5}$ Young researchers club, Tehran central branch, Islamic Azad University, Tehran, Iran \\ E-mail: aras_marine_biology@yahoo.com
}

To facilitate the delivery of genetic material, the use of appropriate carriers such as polymers is necessary. $\mathrm{Na}$ noparticles comprising of chitosan-alginate polymers were formed through pregel preparation method. Chi/Alg nanoparticles had a mean Z-Average diameter of $161.8 \mathrm{~nm}$ and mean zeta $29.3 \mathrm{mV}$, respectively. The ability of plasmidcomplex in preventing DNA migration showed Chi/Alg nanoparticles have great capacity to maintain plasmid. The efficiency of nanoparticles for transfection of pEGFP-N1 plasmid in the cultured HEK 293 cells was measured by flow cytometry. Cell viability assays indicated that nanoparticles had no toxic effect on HEK 293 cells after 4 or $24 \mathrm{~h}$. Our suitable candidate for gene delivery would be Alg/Chi nanoparticles.

Key words: chitosan, alginate, nanoparticle, size, transfection efficiency, cytotoxicity.

Introduction. The basic concept underlying gene therapy is the use of DNA as a pharmaceutical agent for curing diseases. The most currently used gene delivery systems are pharmaceutical nanocarriers, such as polymeric nanoparticles [1-3]. These biodegradable polymers demonstrate useful properties such as non-toxicity, stability and protect gene from degradation and etc [4].

Chitosan and alginate are the most commonly studied polymers in recent years.

Chitosan (Chi) is a cationic polymer which can complex with DNA via electrostatic interactions between anionic phosphate of DNA and amine groups of chitosan [5] and is successfully used as a non-viral gene delivery system both in vitro and in vivo $[6,7]$

Alginate (Alg) is a kind of hydrophilic polysaccharide [8]. Polyanion/polycation cross-linked hydrogel based on alginate and chitosan have gained

(C) A. RAFIEE, F. RIAZI-RAD, M.H. ALIMOHAMMADIAN, T. GAZORI, S.M.R. FATEMI, M. HAVASKARY, 2015

much attention in recent years as carriers for local drug delivery [9].

Chitosan-alginate (Chi/Alg) polyionic complexes are formed through the ionic gelation via interactions between the carboxyl groups of alginate and the amine groups of chitosan [10-13]. The main purpose of this study was to determine the size and physicochemical properties of Chi/Alg pEGFP-N1 complexes. Then the potential of these nanoparticles in cell transfection, preventing DNA migration and their stability in aqueous medium were analyzed. The ability of plasmid-complexes on cell viability was also determined.

Materials and methods. Materials. Sodium alginate (Sigma), Low molecular weight chitosan (Sigma-Aldrich Co., Germany), L-gluthamine, Penicillin, Streptomycin, Fetal bovine serum (FBS) (Biosera, South Korea), PolyFect transfection reagent (Qiagen, Germany), ${ }^{3} \mathrm{H}$-thymidine (Amersham, UK).

Chitosan-alginate nanoparticles preparation for particle size and zeta potential analysis. Chi/Alg nanoparticle preparation of N/P ratio of $5, \mathrm{CaCl}_{2} / \mathrm{Alg}$ ratio of $0.2 \%$, Chi/Alg ratio of 1 and $\mathrm{pH} 5.3$ was performed according to Gazori et al. [14].

Separate stock solutions of $1 \mathrm{mg} / \mathrm{ml}$ sodium alginate and calcium chloride were prepared and $25 \mathrm{mg}$ of chitosan was dissolved in $25 \mathrm{ml}$ of deionized water of $1 \%$ acetic acid solution.

Subsequently, plasmid was allowed to complex with chitosan by vortexing $10 \mathrm{ng}$ plasmid. pEGFP$\mathrm{N} 1$ was prepared with $200 \mathrm{ng} / \mu \mathrm{l}$ concentration with $130 \mu \mathrm{l}(130 \mu \mathrm{g})$ of chitosan from the stock solution mentioned above. The final solution was diluted up to $1 \mathrm{ml}$ with deionized water and then incubated for $30 \mathrm{~min}$ in room temperature. $130 \mu \mathrm{l}$ of sodium alginate from the stock solution was diluted with up to $3 \mathrm{ml}$ filtered deionized water. Then in the case of $\mathrm{CaCl}_{2} / \mathrm{Alg}$ ratio of $0.2 \%, 26 \mu \mathrm{l}$ calcium chloride 
solution was diluted with filtered deionized water up to $1 \mathrm{ml}$ and then added drop wise to alginate solution with the final volume of $4 \mathrm{ml}$ under magnetic stirring condition for $10 \mathrm{~min}$.

Chitosan-plasmid solution was then added drop wise to aforementioned solution for further $30 \mathrm{~min}$ under stirring condition at room temperature. The particle suspension was then centrifuged in Amicon $^{\circledR}$ Ultra-10 (Ultracel-Sok) tube at $4000 \mathrm{rpm}$ for $30 \mathrm{~min}$.

Scanning electron microscopy (LEO1455 VP, $10 \mathrm{KV}$ Cambrige) was used for particle size and morphological characteristic analysis. The particle size and zeta potential were also detected by using Scattering Particle Analyzer and Malvern zeta sizer ZS series, respectively (Malvern, Co., UK).

Gel electrophoresis of nanoparticles. According to the above-mentioned method with the Chi/Alg nanoparticles encapsulating $3 \mu \mathrm{g}$ of plasmid were prepared. After centrifugation at $25{ }^{\circ} \mathrm{C}$ in Amicon ${ }^{\circledR}$ Ultra-10 centrifuge tube, the nanoparticles were all incubated in aqueous medium for 1, 3, 5, 7, 9 and 10 h. $30 \mu \mathrm{l}$ of samples were mixed with loading dye and were electrophoresed for $70 \mathrm{~min}$ run at $120 \mathrm{~V}$ on a $2 \%$ agarose gel and the gel was photographed using gel documentation (Vilber lourmant, Germany).

The ability of chitosan/alginate complex to protect the plasmid against chitosanase and lysozyme were also evaluated. Naked plasmid, chitosan/alginate nanoparticle-DNA complex were treated with 1UDNase I for $15 \mathrm{~min}$ at $37^{\circ} \mathrm{C}$, followed by heat inactivation $\left(60{ }^{\circ} \mathrm{C}\right.$ for $\left.15 \mathrm{~min}\right)$ in the presence of $25 \mathrm{mM}$ EDTA. Nanoparticles were then digested through incubation $\left(4 \mathrm{~h}, 37^{\circ} \mathrm{C}\right)$ with $10 \mu \mathrm{L}$ chitosanase $(48 \mathrm{U} / \mathrm{mL}$ in $50 \mathrm{mM}$ acetate buffer $\mathrm{pH}$ 5.5) and $8 \mu \mathrm{L}$ lysozyme $(0.5 \mathrm{U} / \mathrm{mL}$ in $50 \mathrm{mM}$ acetate buffer pH 5.5) [1]. Samples were then run on a $1 \%$ agarose gel.

Determination of transfection efficiency by flow cytometry. One day before experiment, HEK 293 cells (Pasteur Institute Cell bank of Iran) were cultured in 6 -well plates at $6 \cdot 10^{5}$ cells/well in RPMI supplemented with $10 \%$ fetal bovine serum (FBS), $2.0 \mathrm{mM}$ L-gluthamine, $100 \mathrm{U} / \mathrm{ml}$ penicillin and $100 \mu \mathrm{g} / \mathrm{ml}$ streptomycin in $37^{\circ} \mathrm{C}, 5 \%$ humidified $\mathrm{CO}_{2}$ incubator.

On the day of transfection, the medium was removed and the Chi/Alg nanoparticles $(26 \mu \mathrm{g} / \mu \mathrm{l}$ Chi/Alg and $2 \mu \mathrm{g}$ plasmid were used in all cases)
Fig. 1. SEM images of Chi/Alg nanoparticle. The magnification is $10000 \times$
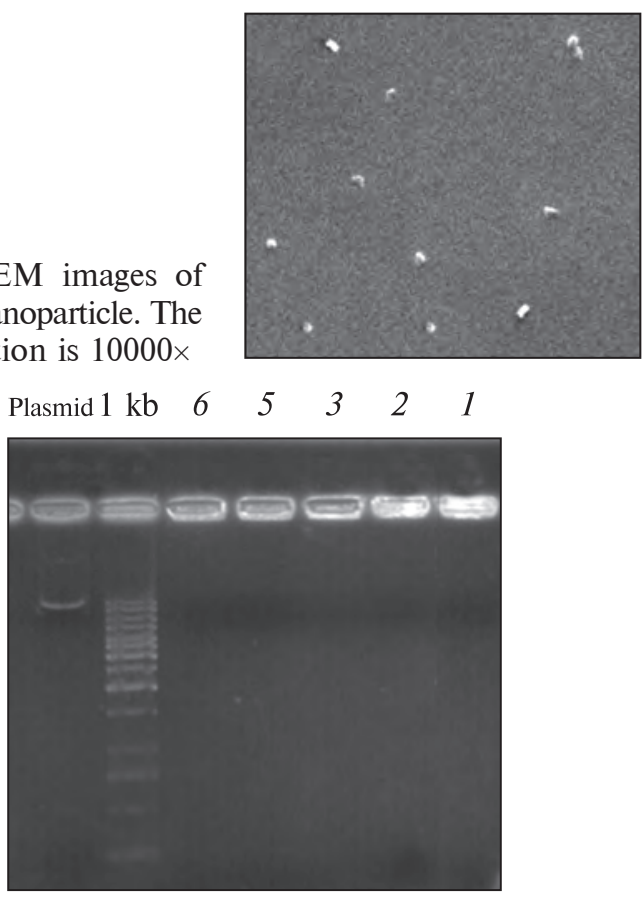

Fig. 2. Agarose gel electrophoresis of Chi/Alg - pEGFP-N1 complexes. Samples were run on a $2 \%$ gel: $1-$ pEGFP-N1 plasmid; 2-1-kb ladder; 3, 4, 5, 6, 7-Chi/Alg - pEGFPN1 complex after 6, 5, 3, 2 and $1 \mathrm{~h}$ incubation

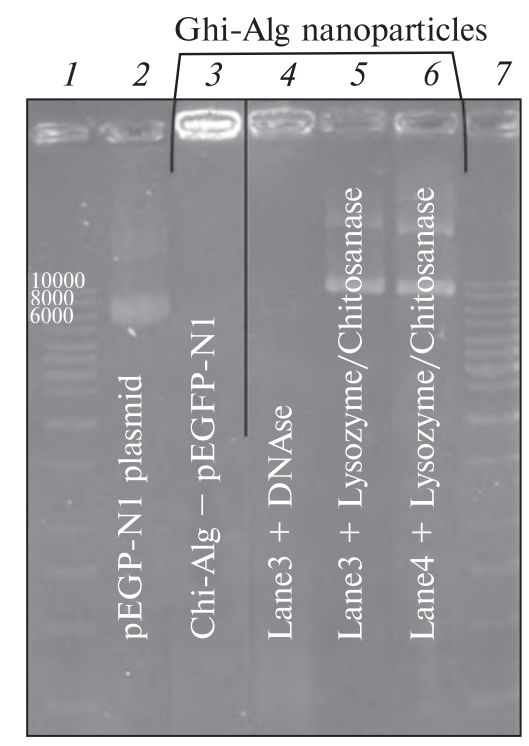

Fig. 3. Agarose gel electrophoresis of Alginate-chitosan plasmid complexes. Samples were run on a $1 \%$ gel: 1 , 7-1-kb ladder; 2- pEGFP-N1 plasmid; 3-Chi-Alg pEGFP-N1; 4-6 - Chi/Alg - pEGFP-N1 following DNAse I, chitosanase/lysozyme and chitosanase/lysozyme/DNAse I digestion 

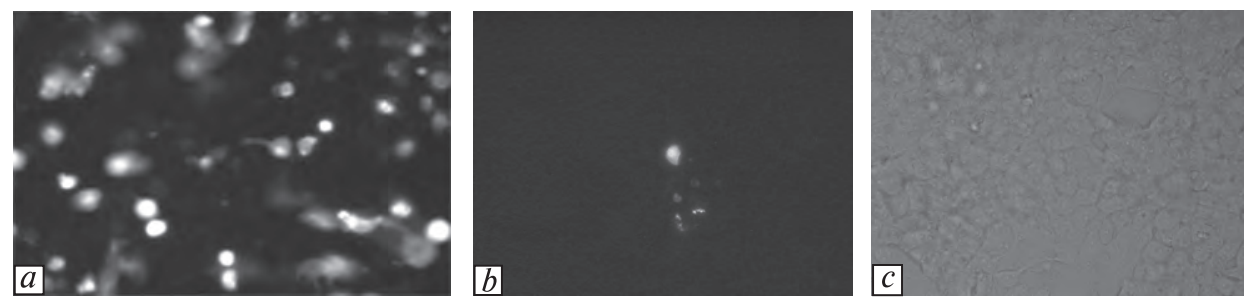

Fig. 4. Fluorescent microscopy imaging of the transfected cells as $400 \times$ magnification: $a$ - the transfected HEK 293T cells showed the GFP expression for polyfect; $b-\mathrm{GFP}$ expression for Chi/Alg nanoparticles; $c-$ the cells in visible light

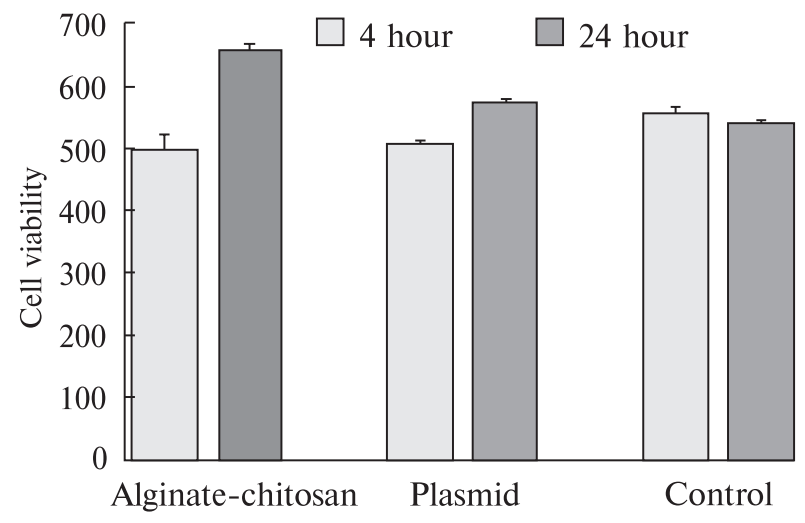

Fig. 5. Cytotoxicity of alginate-chitosan-plasmid nanoparticles compared with plasmid alone and control. The HEK 293 cells were cultured in 96-well plates and were exposed to $10 \mu \mathrm{g}$ plasmid and Chi/Alg - pEGFP-N1 nanoparticles $(26 \mu \mathrm{g} / \mathrm{ml})$ and negative control (medium cell culture (RPMI)). All data are presented as mean of three different measurements $\pm \mathrm{SE}$

were added to the cells. Polyfect TM $(10 \mu \mathrm{l})$ loaded with 10 ng pEGFP-N1 was also used as a control. At $48 \mathrm{~h}$ post-transfection, the medium was removed and the cells were washed with buffered saline (PBS). Expression of EGFP was first visualized by fluorescent microscopy (Leitz Germany) and the transfection efficiency percentage was determined by flow cytometry (BD, FACScan).

Cytotoxicity assay and statistical analysis. About $1 \cdot 10^{4}$ cells/well HEK 293 cells were cultured in 48-well plate in $180 \mu \mathrm{l}$ of complete growth medium. After $48 \mathrm{~h}$, Chi/Alg - pEGFP-N1 nanoparticles $(26 \mu \mathrm{g} / \mathrm{ml})$ and $10 \mu \mathrm{g}$ pEGFP-N1 alone was added to the cells in triplicate with for 4 and $24 \mathrm{~h}$. Control cells were treated only with the culture medium. After exposure times, all the media were replaced with fresh complete growth medium and the plates were incubated at $37{ }^{\circ} \mathrm{C}$ and $5 \% \mathrm{CO}_{2}$. One $\mu \mathrm{Ci} / \mathrm{ml}^{3} \mathrm{H}$-thymidine (Sigma,
USA) was added to the cells for a further $16 \mathrm{~h}$. Finally, the incorporated radioactive label activity was determined using a beta-counter (Wallac). Statistical significance was determined using students' two-sided $t$-test with $p<0.05$ deemed significant.

Results and discussion. Zeta potential analysis of the nanoparticles. Nanoparticles of Chi/Alg had an average size of $161.8 \mathrm{~nm}$ (Fig. 1) and a strongly positive charge of $+29.3 \mathrm{mV}$.

According to Rieux 2006, the optimum size of nanoparticles that can be absorbed by enterocytes is 100-200 nm [15] which shows that our Chi/ Alg nanoparticles $(161 \mathrm{~nm})$ are also in appropriate size for mucosal absorption. Indeed, the majorities of amine groups of chitosan were protonated at pH 5.3 and were able to participate in electronic interactions with carboxyl group of alginate. Here, alginate can be cross-linked with the pEGFP-N1 using polyvalent cations such as $\mathrm{Ca}^{2+}[16,17]$.

Gel electrophoresis of nanoparticles. Electrophoresis analysis was conducted to assess the stability of Chi/Alg - pEGFP-N1 (1, 2, 3, 5 and 6) after synthesis. It can be seen from Fig. 2 that pDNA wrapped in Chi/Alg nanoparticles was unable to move and remained in the loading wells even after $6 \mathrm{~h}$ post synthesis.

For the purpose of evaluating the ability of Chi/Alg nanoparticles to protect DNA, its integrity was evaluated following complexation and release from nanoparticleas, with and without exposure to nucleases. Chi/Alg nanoparticles showed capacity of protecting DNA from enzymatic digestion (Lane $4,5,6)$. As illustrated in Fig. 3, plasmids complexed with Chi/Alg nanoparticles were protected from digestion, as demonstrated by the release of plasmid following inactivation of Dnase I and degradation of the nanoparticles (Lane 5, 6).

In vitro transfection. Cellular uptake of Chi/Alg nanoparticles was investigated using the green fluo- 
rescent protein plasmid (pEGFP-N1 - $4.7 \mathrm{~kb})$ and were compared to polyfect transfection. Two days after transfection, the cells emitted the green fluorescence (Fig. 4, a) under the immunofluorescent microscope.

Flow cytometric analysis of the transfected cells indicated 68 and $42 \%$ GFP expression for polyfect and $\mathrm{Chi} / \mathrm{Alg}$ nanoparticles, respectively. The results show that nanoparticles transfection and expression efficiency was less than polyfect/plasmid.

In fact, positive charge of amine groups of chitosan can complex with negative charge of DNA phosphate which results in low gene transfection efficiency [18]. Therefore incorporation of negatively charged polymer such as alginate decreases the strength of interaction between DNA and chitosan. This should increase the transfection efficiency of the system by facilitating the release of DNA once the particles have been internalized by cells $[19,20]$. However, other mechanisms of endosomal release such as swelling of the polymer due to its hydrogel effect may increase the release of pEGFP into the cytosol [21-23].

Toxicity of nanoparticles. The effect of the nanoparticle-plasmid complexes on the cell viability was determined using cytotoxicity assay. As illustrated in Fig. 5, Chi/Alg nanoparticles showed no toxicity and no difference compared to the control after $4 \mathrm{~h}$ but had higher cell viability after $24 \mathrm{~h}(\mathrm{p}<$ $<0.05)$. These results showed that alginate and chitosan increased the cell proliferation by influencing on mitochondrial activity of the cells, stimulating them to proliferate [21].

Conclusion. In this study $\mathrm{Chi} / \mathrm{Alg}$ nanoparticles have prepared with Chi/Alg ratio of $1, \mathrm{CaCl}_{2} / \mathrm{Alg}$ ratio of $0.2 \%$ and $\mathrm{N} / \mathrm{P}$ ratio of 5 at $\mathrm{pH} 5.3$. The great amine groups of chitosan were protonated at $\mathrm{pH} 5.3$ and had electrostatic interactions with plasmid which could limit the release of pDNA by chitosan. Therefore Chi/Alg nanoparticles mediated transfection of HEK cells, resulted in $42 \%$ transfection. This shows the effect of alginate on reducing the strength of electrostatic interactions between chitosan and pDNA, resulting in better transfection and increasing the plasmid release.

Moreover, an average size of Chi/Alg nanoparticles was $161.8 \mathrm{~nm}$ with mean zeta potential of $29.3 \mathrm{mV}$, providing characteristics desirable for gene delivery. Also unlike the intact pDNA, pDNA encapsulated in Chi/Alg nanoparticles weren't re- leased after $6 \mathrm{~h}$ which makes it a good candidate for pDNA protection.

ПЛАЗМИДЫ, ИНКАПСУЛИРОВАННЫЕ В ГИДРОГЕЛЬНЫЕ НАНОЧАСТИЦЫ, КАК ПОДХОДЯЩАЯ СИСТЕМА ДОСТАВКИ ГЕНОВ

A. Rafiee, F. Riazi-rad, M.H. Alimohammadian, T. Gazori, S.M.R. Fatemi, M. Havaskary

Islamic Azad University, Tehran, Iran

E-mail: aras_marine_biology@yahoo.com

Для облегчения доставки генетического материала необходимо использование подходящих носителей, таких как полимеры. Наночастицы, состоящие из хитозан-альгинатных полимеров, были получены методом подготовки прегеля. Chi/Alg наночастицы имели средний диаметр 161.8 нм (Z-Average) и средний zeta-потенциал $29.3 \mathrm{mV}$. Отсутствие миграции ДНК во время электрофореза комплексов плазмиды с наночастицами показало, что Chi/Alg наночастицы могут удерживать плазмидную ДНК внутри комплекса. Эффективность наночастиц для трансфекции плазмиды pEGFP-N1 в культивируемые клетки НЕК 293 была измерена с помощью жидкостной цитометрии. Тесты на жизнеспособность клеток показали, что наночастицы не имели токсичного эффекта на клетки HЕК 293 через 4 ч или 24 ч. Наночастицы $\mathrm{Alg} / \mathrm{Chi}$ являются подходящим кандидатом для доставки генов.

\section{REFERENCES}

1. Douglas K.L., Piccirillo C.A., Tabrizian M. Effects of alginate inclusion on the vector properties of chitosan-based nanoparticles // J. Control. Release. 2006. - 115, № 3. - P. 354-361.

2. Alonso M.J. Nanomedicines for overcoming biological barriers // Biomed. Pharmacother. - 2004. - 58, № 3. - P. 168-172.

3. Hama S., Akita H., Iida S. et al. Quantitative and mechanism-based investigation of post-nuclear delivery events between adenovirus and oligoplex // Nucl. Acids Res. - 2007. - 35. - P. 1533-1543.

4. Liu Z., Jiao Y., Wang Y. et al. Polysaccharids-based nanoparticles as drug delivery systems // Adv. Drug. Deliv. Rev. - 2008. - 60. - P. 1650-1662.

5. Kumar M.N., Muzzarelli R.A., Muzzarelli C. et al. Chitosan chemistry and pharmaceutical perspectives // Chem. Rev. - 2004. - 104. - P. 6017-6084.

6. Kumar M., Kong X., Behera A.K. et al. Chitosan IFNgamma-pDNA nanoparticle (CIN) therapy for allergic asthma // Genet Vaccines Ther. - 2003. - 1, № 1. - P. 3-13.

7. Chen J., Yang W.L., Li G. et al. Transfection of mEpo gene to intestinal epithelium in vivo mediated by oral delivery of chitosan-DNA nanoparticles // World 


\section{A. Rafiee, F. Riazi-rad, M.H. Alimohammadian et al.}

J. Gastroenterol. - 2004. - 10, № 1. - P. 112116.

8. Lertsutthiwong P., Noomun K., Jongaroonngamsang $N$. et al. Preparation of alginate nanocapsules containing turmeric oil // Carbohydr. Polym. - 2008. - 74, № 2. - P. 209-214.

9. Simonoska Crcarevska M., Glavas-Dodov M., Goracinova $K$. Chitosan coated Ca-alginate microparticles loaded with budesonide for delivery to the inflamed colonic mucosa // Eur. J. Pharm. Biopharm. - 2008. 68, № 3. - P. 565-578.

10. Mladenovska K., Cruaud O., Richomme P. et al. 5ASA loaded chitosan-Ca-alginate microparticles: preparation and physicochemical characterization // Int. J. Pharm. - 2007. - 345, № 1. - P. 59-69.

11. Bagre A.P., Jain K., Jain N.K. Alginate coated chitosan core shell nanoparticles for oral delivery of enoxaparin: in vitro and in vivo assessment // Int. J Biol. Macromol. - 2013. - 456, № 1. - P. 31-40.

12. Motwani S.K., Chopra Sh., Talegaonkar S. et al. Chitosan-sodium alginate nanoparticles as submicroscopic reservoirs for ocular delivery: formulation, optimisation and in vitro characterization // Eur. J. Pharm. Biopharm. - 2008. - 68, № 3. - P. 513525.

13. Yan X.L., Khor E., Lim L.Y. Chitosan-alginate films prepared with chitosans of different molecular weights // J. Biomed. Mater. Res. - 2001. - 58, № 4. - P. 358-365.

14. Gazori T., Khoshayand M.R., Azizi E. et al. Evaluation of Alginate/Chitosan nanoparticles as antisense delivery vector : Formulation, optimization and in vitro characterization // Carbohydr. Polym. - 2009. 77, № 3. - P. 599-606.

15. Rieux A. des, Fievez V., Garinot M. et al. Nanoparticle as potential oral delivery systems of proteins and vaccines : A mechanistic approach // J. Control. Release. - 2006. - 116, № 1. - P. 1-27.
16. Chan L.W., Lee H.Y., Heng P.W.S. Mechanisms of external and internal gelation and their impact on the functions of alginate as a coat and delivery systems // Carbohydr. Polym. - 2006. - 63, № 2. P. 176-187.

17. Guo R., Chen L., Cai S. et al. Novel alginate coated hydrophobically modified chitosan polyelectrolyte complex for the delivery of BSA // J. Mater. Sci. Mater. Med. - 2013. - 24, № 9. - P. 2093-2100.

18. George M., Abraham T.E. Polyionic hydrocolloids for the intestinal delivery of protein drugs : Alginate and chitosan - a review // J. Control. Release. - 2006. 114, № 1. - P. 1-14.

19. Duceppe N., Tabrizian M. Factors influencing the transfection efficiency of ultra low molecular weight chitosan/hyaluronic acid nanoparticles // Biomaterials. - 2009. - 30, № 13. - P. 2625-2631.

20. Peng S.F., Yang M.J., Su C.J. et al. Effects of incorporation of poly $(\gamma$-glutamic acid) in chitosan/DNA complex nanoparticles on cellular uptake and transfection efficiency // Biomaterials. - 2009. - 30. P. 1797-1808.

21. Dupuy B., Arien A., Birrot Minnot A. FT-IR of membranes made with alginate/polylysine complexes. Variations with, the mannuronic or guluronic content of the polysaccharides // Artif. Cells Blood Substit. Immobil. Biotechnol. - 1994. - 22, № 1. P. 71-82.

22. You J.O., Peng C.A. Calcium-Alginate nanoparticles formed by reverse microemulsion as Gene Carriers // Macromol. Symp. - 2004. - 219, № 1. - P. 147153.

23. Sonawane N.D., Szoka F.C.Jr., Verkman A.S. Chloride accumulation and swelling in endosomes enhances DNA transfer by polyamine-DNA polyplexes // J. Biol. Chem. - 2003. - 278. - P. 4482644831 .

Received 23.07.13 